\title{
ROZHL'ADY
}

\section{KONŠTITUOVANIE HINDČINY AKO ÚRADNÉHO JAZYKA INDIE}

\author{
PETER NAGY \\ Filozofická fakulta UK, Praha
}

\begin{abstract}
NAGY, Peter: Constituting of Hindi as an official language of India. Journal of linguistics, 2014, Vol. 65, No 2, pp. $157-169$.

Abstract: The article deals with the Hindi language and its use as a language for official purposes from the late Middle Ages until its implementation in the Constitution of India in the year 1949. It reveals various ideas for promoting Hindi as a national (official) language of India. The main focus is on the thoughts of Mahatma Gandhi on Hindi as the lingua franca of India and its role in the replacement of English. Further it describes the process and struggle of its implementation as the official language in the Constituent Assembly of India and concludes with the compromise made by this Assembly.
\end{abstract}

Keywords: Hindi, Urdu, Hindustani, Gandhi, Official Language, Constitution of India

\section{1. ÚVOD}

India vstupovala do modernej doby ako britská kolónia. Všetka komunikácia štátnej správy $\mathrm{v}$ tom období prebiehala $\mathrm{v}$ prvom rade $\mathrm{v}$ anglickom jazyku. $\mathrm{Z}$ toho dôvodu si poprední činitelia národnooslobodzovacieho hnutia začali klást’ otázku, čo by malo nahradit' angličtinu ako celoindický úradný jazyk, ktorá v tom čase niesla stigmu jazyka kolonizátorov. Mahátma Gándhí (ale aj mnohí iní pred ním) presadzoval ideu, že nezávislá India má mat’ svoj národný jazyk spomedzi domácich jazykov a nie materinský jazyk kolonizátorov. Ako najvhodnejš́ sa mu javila práve hindustánčina, ktorá bola v tom období najrozšírenejšś hovorový jazyk Indie a ktorej pomenovanie sám presadzoval. Tento jazyk však - ako každý hovorový - plnil len obmedzené funkcie v každodennom styku l’udí najrôznejších spoločenských vrstiev, najmä tých menej vzdelaných. Vzdelané vrstvy používali kultivovanejší variant nazývaný hindčina, ak išlo o hinduistov, ktorá slovnú zásobu čerpala zo sanskrtu, respektíve urdčina, ak išlo o moslimov, ktorí preferovali perzsko-arabské výrazy. Oba varianty, tak ako aj hindustánčina, vychádzajú z dialektu kharibólí, ktorým sa hovorí v okolí dnešného Dillí. Ako ,pridružený“ úradný jazyk sa používala popri angličtine už počas britskej koloniálnej nadvlády. Proces jej konštituovania ako úradného jazyka sa pokúsime stručne opísat' v tomto článku. 


\section{VÝVOJ HINDČINY A JEJ POSTAVENIE AKO ÚRADNÉHO JAZYKA PRED ROKOM 1947}

Hindčina, respektíve jej dialekty, sa začala vyvíjat’ ako ostatné novoindické jazyky (bengálčina, pandžábčina a iné) na prelome 1. a 2. tisícročia n. 1. z prákrtov, respektíve z ich poslednej fázy nazývanej apabhramša. Forma apabhramše zvaná šauraséní apabhramša dominovala ako literárny jazyk v období od 9. do 14. storočia v celej Severnej Indii. Podl'a Sunítikumára Čaterdžího „šauraséní apabhramša bola $\mathrm{v}$ tom čase medziregionálnym jazykom. Pochádzajú z nej moderná bradžština, kharíbólí a iné dialekty hindčiny. Podobne ako hindčina dnes, používala sa na rozsiahlom území Indie ako jazyk medzi regiónmi, čítali a písali v nej všetci Indoárijci“ (Čaterdží, 1957, s. 120). ${ }^{1}$

Hindčina sa $\mathrm{v}$ tomto období nevyvinula $\mathrm{z}$ apabhramše ako jednoliaty jazyk, ale ako súbor rôznych dialektov, ktoré sa až do dnešnej doby používajú ako hovorové varianty hindčiny v tzv. Hindskom páse (angl. Hindibelt). Z týchto dialektov boli pre formovanie hindčiny ako kultúrneho jazyka najvýznamnejšie avadhský, bradžský dialekt a kharíbólí (posledný je dnes základom nielen úradnej (spisovnej) hindčiny, ale aj urdčiny).

Najranejšou formou literárnej hindčiny bol jazyk dingal (vznikol v oblasti zahrnujúcej približne dnešný Gudžarát a Radžastan (Rádžasthán) v Indii a Sindh v Pakistane), ktorý sa používal približne od 11. do 14. storočia. V ňom bola napísaná literatúra tzv. hrdinských eposov (rásó), z ktorých najznámejší je Prthvirádža rásó od Čandbardáího. V neskoršom období tento dialekt ako literárnu formu hindského jazyka nahradili iné nárečia.

Rozvoj dialektov avadhí a bradž súvisí so vznikom nového filozoficko-náboženského hnutia hinduizmu, tzv. bhakti. To nadobudlo dve najvýraznejšie formy, rámaistickú a krišnaistickú bhakti. Podl'a centier, v ktorých sa príslušné hnutie pestovalo, sa ujal aj zodpovedajúci dialekt. Pre rámaistickú bhakti sa používal avadhský dialekt, pretože centrom Rámovho kultu bola Ajódhja (Faizábád v dnešnom Uttarpradéši), v ktorej okolí sa tento dialekt používa. Najvýznamnejším dielom tohto dialektu je Rámčaritmánasa od Tulsí Dása (1532 - 1623). Ide o populárne dielo staršej hindskej literatúry a súčasní Indovia Rámove príbehy poznajú skôr z tohto diela než z pôvodnej Válmíkiho Rámájany.

Bradžský dialekt je na druhej strane literárnou formou krišnaistickej bhakti, ktorá mala centrum $\mathrm{v}$ oblasti miest Mathura a Vrindávan, nachádzjúcich sa $\mathrm{v}$ dnešnom Uttarpradéši medzi Dillí a Ágrou. Ako jazyk poézie sa udržala v hindskej literatúre až do 20. storočia. Písali ňou nielen autori, ktorých rodným jazykom bol niektorý z hindských dialektov, ale aj používatelia iných novoindických jazykov, ako napríklad poetka „Krišnova manželka“ Mírá Báí (16. stor.), ktorej rodným jazy-

${ }^{1}$ Citáty z cudzojazyčných (hindských, ruských a anglických) prameňov do slovenčiny preložil autor príspevku. 
kom bola podla jej vlastných slov gudžarátčina, alebo zakladatel' sikkhizmu Pandžábec Guru Nának (1469 - 1539). Najznámejším dielom tohto dialektu je Súrságar od ospevovaného autora Súrdása (asi 1483 - 1563). Je to súvislý básnický epos, ktorý je vlastne novým prebásnením Bhagavatpurány. Literárna tvorba z tohto obdobia (15. - 16. storočie) mala vplyv na presadenie bradžštiny ako jazyka poézie aj mimo hraníc Hindského pásu a aj na dvoroch moslimských vládcov (Barannikov, 1972, s. 73).

Dialekt kharíbólí vznikol v Dillí a jeho pril'ahlom okolí. Táto oblast' sa stala centrom Dillískeho sultanátu (1206 - 1526), ktorý počas svojho najväčšieho rozmachu teritoriálne zahrnoval takmer celú dnešnú Indiu. Úradným jazykom tohto štátneho útvaru bola perzština, avšak rozširovaním územia čoraz väčšmi do vnútrozemia Indie vyvstala potreba používat' aj nejaký miestny indický jazyk. Ked’že centrum bolo v Dillí, bolo prirodzené, že sa ním stal dialekt kharíbólí a vo svojej administratíve ho začal používat' sultán Aláuddín Chaldží (Childží) začiatkom 14. storočia. Básnik Amír Chusró (Chusrau), ktorý písal svoje verše nielen v perzštine, ale práve aj v dillískom dialekte hindčiny, bol poverený Aláuddínom, aby zostavil slovník bežných slov používaných $\mathrm{v}$ hindčine, pandžábčine a bradžštine s ekvivalentmi v perzštine.

Kharíbólí síce nezískal v stredovekej hindskej literatúre takú prestíž ako vyššie uvedené dialekty, ale postupom času zatlačil všetky hindské dialekty do úzadia a od 19. storočia sa stal výlučným základom modernej hindčiny. Čoraz väčším prenikaním perzských a arabských slov, ktoré do tohto dialektu priniesli moslimskí vojaci, ale aj úradníci či obchodníci z Perzie, sa vyvinula urdčina, ktorá odvodzuje svoj názov z turkického ordu (armáda, vojenský tábor). S prienikom Dillískeho sultanátu do južnej Indie sa sem dostala aj hindčina, respektíve urdčina, ktorá sa ujala ako úradný jazyk Haidarábádskeho sultanátu a dodnes sa ňou hovorí v okolí Haidarábádu (zväzový štát Telangána), ale označuje sa ako južná urdčina (dakkhiníurdú), lebo sa čiastočne odlišuje od severnej formy, súc po stáročia pod vplyvom drávidskych jazykov a maráthčiny (porov. Gopal, 1966, s. 157 - 160).

Nástupom Mughalskej dynastie k moci (1526) si podržala svoje výnimočné postavenie úradného jazyka perzština, ktorá bola aj rokovacím jazykom súdov. Po porážke bengálskeho navába Sirádžuddaulu Angličanmi pri západobengálskom Paláší 23. júna 1757 až do tridsiatych rokov 19. storočia perzštinu ako úradný jazyk používala aj Východoindická spoločnost'. V hindsky hovoriacich oblastiach ovládaných Spoločnost'ou sa nariadenia určené pre l'udové masy prekladali z angličtiny do hindčiny (Gopal, 1966, s. 161).

V tomto čase sa v severnej Indii začali verejné diskusie ohl'adne národného jazyka. Prvý významný indický politik tej doby Rámmohan Ráj sa vyjadril v prospech angličtiny, lebo $\mathrm{v}$ nej videl prostriedok osvietenstva v porovnaní so sanskrtom, ktorý by krajinu ponechal $\mathrm{v}$ dobe temna. Podobne sa vyjadrila aj Rada direktorov Východoindickej spoločnosti, ktorá svojej vláde v Indii odporučila angličtinu ako úradný 
jazyk a prostriedok komunikácie s miestnymi kniežatami. Na druhej strane však odporučila, aby sa používanie angličtiny netýkalo súdov, kde by sa mala dat' prednost' jazyku, ktorému rozumie miestne indické obyvatel'stvo.

Rozhodnutie padlo najprv na urdčinu, nielen preto, že bola miestnym indickým jazykom, ale zavážil aj argument, že jej perzsko-arabské písmo nespôsobí administratívne problémy, nezvýši náklady súdov, ako by si to vyžadoval d’alší návrh počítajúci s hindčinou a jej písmom dévanágarí. Tento proces sa začal najprv v Biháre v polovici 19. storočia, aby pokračoval v severozápadných provinciách a neskôr aj v centrálnych provinciách. Prechod z perzštiny na urdčinu sa ukázal ako neúčinný, pretože súdy síce používali miestny indický jazyk, ale tak presýtený perzskými výrazmi, že zmena nebola vôbec badatel'ná a roztržky kvôli nezrozumitel'nosti rokovacieho jazyka pretrvávali nad’alej. Nakoniec padlo definitívne rozhodnutie v prospech hindčiny, respektíve hindustánčiny, ktorá nebola až tak vystavená tlaku zo strany perzštiny ako urdčina. ${ }^{2} \mathrm{~S}$ tým súvisel aj výber písma, ked’ sa dala prednost' dévanágarí pred perzsko-arabským písmom, pretože písmu dévanágarí bolo podobné písmo bengálske a uríske, takže obyvatelia s ním nemali také t’ažkosti ako s úplne cudzím perzsko-arabským písmom. Toto rozhodnutie malo oporu aj vo fakte, že maráthski a nepálski vládcovia uprednostňovali na svojom území na úradné účely hindustánčinu a písmo dévanágarí, pretože úradníci sa ich l'ahšie naučili než angličtinu (Gopal, 1966, s. $161-163)$.

Zavádzanie hindčiny ako d’alšieho úradného a rokovacieho jazyka popri angličtine vyvolalo námietky zo strany niekol'kých oponentov, medzi ktorých patril aj G. A. Grierson. Ten poukazoval na to, že ,jazyk, ktorý sa nazýva hindčina, nie je jazykom 90 \% obyvatel'stva Biháru; že písaná hindčina, ktorú dala vláda vytvorit’ spísaním Prém Ságaru od Lallú Lála, je umelým jazykom; a že mnoho slov v hindčine je nezrozumitel'ných moslimom" (Gopal, 1966, s. 166). Preto navrhoval, aby sa „,hindčina nezavádzala do škôl a na súdy; miesto nej by sa mal použit’ niektorý z tých jazykov, ktorými sa hovorí na území Biháru: baisvárí, gánvadí, maithilí, magahí, bhódžpuri'“ (Gopal, 1966, s. 167).

Jeho návrhy mali ten nedostatok, že nimi chcel zaviest’ do úradnej sféry regionálne jazyky, ktoré ani nemali literárnu tradíciu. Opieral sa o svoju klasifikáciu indických jazykov, v ktorej mnohým dialektom prisúdil postavenie samostatných jazykov a ignoroval fakt, že kharíbólí bol už v tom čase mestským jazykom Biháru (Čaterdží, 1957, s. 161).

Ku koncu 19. storočia sa začali ozývat’ hlasy za výlučné zavedenie hindčiny namiesto angličtiny. Medzi najväčších zástancov tejto myšlienky patrili Bál Gangádhar Tilak, Kešab Čandra Sen, Rádž Nárájan $\mathrm{Basu}^{3}$ a iní. Hindčina však nebola materčinou ani jedného z týchto l'udí. Takisto Dajánanda Sarsvatí, Gudžarátec, bol

${ }^{2}$ Treba pripomenút' fakt, že na druhej strane perzština dlhodobým súžitím s indickými jazykmi severnej Indie značne ovplyvnila ich slovnú zásobu, a to aj výrazmi z každodenného života.

${ }^{3}$ Anglicky Bose. 
presadzovatel'om hindčiny a trval na tom, aby l'udia z rôznych provincií vo vzájomnej korešpondencii používali hindčinu namiesto angličtiny (Gopal, 1966, s. 175 $-176)$.

Indický národný kongres sa na začiatku 20. storočia po vytvorení Moslimskej ligy (do ktorej prešlo mnoho jeho členov, za všetkých spomenieme Muhammada Alího Džinnáha, zakladatel'a a prvého generálneho guvernéra Pakistanu) a schválení oddelených volieb pre hinduistov a moslimov snažil zabránit' d’alšiemu vzájomnému vzd’al'ovaniu týchto komunít postupným osvojením si myšlienky hindustánčiny ako zmesi jednoduchej hindčiny a urdčiny, ktorá sa bude písat' v dévanágarí, ako aj perzsko-arabským písmom (Gopal, 1966, s. 177). Najväčším nadšencom tejto myšlienky na pôde Kongresu bol Mahátma Gándhí. Gándího názorom na túto tému sa venujeme v nasledujúcej časti.

\section{PREDSTAVY INDOV O HINDČINE AKO ÚRADNOM JAZYKU}

V priebehu snáh o získanie nezávislosti od Británie si Indovia začali uvedomovat', že v administratíve bude potrebné nahradit' anglický jazyk inou rečou pochádzajúcou $\mathrm{z}$ domáceho indického prostredia. $\mathrm{Z}$ novoindických jazykov si najväčšiu podporu získala hindčina, a to aj vd’aka M. K. Gándhímu, ktorý po celý svoj politický život bol jej neúnavným zástancom a podporovatel'om. Sám k tomuto problému napísal: „Píšeme si navzájom v zlej angličtine a nie sú od toho ochránení ani naši bakalári slobodného umenia. Naše najlepšie myšlienky sú vyjadrené v angličtine, rokovania nášho Kongresu prebiehajú $\mathrm{v}$ angličtine, naše najlepšie noviny vychádzajú v angličtine. Ak tento stav potrvá nad’alej, naše potomstvo nás, a o tom som pevne presvedčený, odsúdi a prekl'aje“ (Gándhí, 2003, s. 75). Na zasadaní 2. gudžarátskej vzdelávacej konferencie v Bharúči Gándhí vo svojom príhovore okrem iného načrtol, čo si predstavuje pod jazykom, ktorý Indovia majú prijat' za svoj národný. Zhrnul to do nasledujúcich bodov: „1. Musí byt' l'ahko naučitel'ný pre štátnych úradníkov; 2. Musí byt' schopný slúžit' ako prostriedok náboženského, ekonomického a politického styku v celej Indii; 3. Musí íst' o jazyk, ktorým hovorí väčšina obyvatel'ov Indie; 4. Musí byt' l'ahko naučitel’ný pre všetkých v krajine; 5 . Pri vol'be tohto jazyka sa nemajú brat' ohl'ady na dočasné alebo pominutel'né záujmy. Ktorý jazyk spíňa všetky tieto požiadavky? Musíme pripustit', že je to hindčina“" (podl'a. Gopal, 1966, s. $180-181)$.

Okrem hindčiny sám Gándhí považoval za d’alší jazyk, ktorý by spíňal tieto podmienky, bengálčinu. Ako sám povedal, „(Ale) samotní Bengálci mimo Bengálska používajú hindčinu. Človek ktorý hovorí hindsky, používa hindčinu, kdekolvek sa nachádza, a nikoho to neprekvapuje“ (podl’a Gopal, 1966, s. 181).

Hindčina bola relatívne l'ahkým jazykom na naučenie pre tých, ktorých materčinou bol jazyk z indoeurópskej jazykovej rodiny. Iná situácia bola u tých, ktorí ho- 
vorili niektorým z drávidských jazykov. Gándhí sa domnieval, že hindčina je vhodná aj pre nich, pretože „(síce) ich štruktúra a gramatika sa líšia od sanskrtu. To, čo spája obe tieto skupiny, je ich slovná zásoba pochádzajúca zo sanskrtu... Máme právo apelovat' na ich patriotického ducha a očakávat' od nich zvýšené úsilie pri učení sa hindčiny“" (podl'a Gopal, 1966, s. 182).

Celý zvyšok svojho života bol M. K. Gándhí neúnavným propagátorom indických jazykov. Presviedčal l'udí, aby opustili angličtinu a obrátili sa k svojmu rodnému jazyku a hindčine. Sám v tejto súvislosti napísal: „Cudzie médium (angličtina pozn. P. N.) urobilo z našich detí cudzincov v ich vlasti. Keby som mal moc despotu, dnes by som zastavil vyučovanie našich chlapcov a dievčat v cudzom médiu a prinútil všetkých učitel'ov a profesorov pod hrozbou prepustenia, aby uskutočnili v tomto smere zmenu“" (podl'a Gopal, 1966, s. 183).

Gándhího viedlo úsilie nahradit' angličtinu hindčinou $\mathrm{k}$ tomu, že presviedčal všetkých, pre ktorých hindčina nebola materčinou, aby sa snažili nadobudnút' čo najskôr obstojnú znalost' tohto jazyka. Jej štúdium považoval za také jednoduché, že tvrdil: „Bengálec sa naučí hindčinu za dva mesiace, ak jej venuje tri hodiny denne, a Drávid za šest' mesiacov pri rovnakom tempe“ (podl’a Gopal, 1966, s. 183).

Okrem hindčiny sa snažil presadzovat’ aj miestne jazyky, ktoré mali na regionálnej úrovni plnit’ tú istú úlohu ako národný jazyk na celoštátnej: „Prvým krokom by malo byt' jazykové a politické prerozdelenie provincií... V súvislosti s pozdvihnutím statusu a trhovej hodnoty regionálnych jazykov ustanovil by som jazykom súdu jazyk provincie, v ktorej sa súd nachádza... Navrhujem zákonodarcom, že by mohli pri dostatočnom úsilí v priebehu mesiaca pochopit’ jazyk provincie, v ktorej pôsobia. Nič nebráni Tamilovi, aby sa naučil jednoduchú gramatiku a pár sto slov z telugčiny, malajálamčiny a kanarčiny, ktoré sú podobné tamilčine“(Gopal, 1966, s. 185). Ukazuje sa tu nereálnost' Gándhího názoru o tempe, ktorým sa dá zvládnut hoci aj príbuzný jazyk, pretože neberie do úvahy, že nie všetci l'udia sú jazykovo nadaní a dokážu rýchlo zvládnut' cudzí jazyk.

\subsection{SLOVNÁ ZÁSOBA}

Hindčina, ktorú v tom čase presadzoval Gándhí a iní, bola tesne spojená s urdčinou. S touto skutočnost'ou súviselo najmä Gándhím presadzované pomenovanie hindustánčina, ktorá sa dnes považuje za hovorovú formu hindčiny a urdčiny. Kanaiyálál Mániklál Munší celkom výstižne vyjadruje tento stav, ked’ vraví: „V skutočnosti hindčina a urdčina neboli rozdielne jazyky. Nechajúc bokom malú vzdelanú čast', obyvatelia Zjednotených provincií ${ }^{4}$ hovorili len jedným jazykom, v ktorom bolo možné nájst' sanskrtské, perzské a lokálne prvky na rôznych úrovniach. Ten, kto používal väčšie množstvo perzských slov, hovoril urdčinou. Ten, kto použival väčšie množstvo sanskrtských a lokálnych slov, hovoril hindčinou. L’udia na ulici používali len slová bežného života bez ohl'adu na ich pôvod. Tento živý jazyk bol

${ }^{4}$ Približne dnešný Uttarpradéš a z časti Uttarákhand. 
označovaný úradníkmi pri sčítaní l'udu ako hindustánčina, hinduistami ako hindčina a moslimami ako urdčina“" (Munshi, 2006, s. 49).

Predstavy vtedajších Indov týkajúce sa slovného fondu národného jazyka zretel'ne vyjadruje Káká Kálélkar vo svojom článku Národný jazyk pre Indiu takto: „Dnes sa bude naša hindustánčina skladat' zo všeobecne zrozumitel'ných slov z hindčiny a urdčiny a spolu s nimi aj z takých slov z paňdžábčiny, rádžastánčiny, bihárčiny, bundélkhandčiny, bengálčiny, gudžarátčiny, maráthčiny, kanarčiny a pod., ktoré sú najviac zrozumitel'né. Tak napríklad slovíčko zamín bude populárnejšie ako slovíčko bhúmi a slovko káran bude viac používané ako vadžah. Ale obe varianty budú považované za správne.

Národný jazyk patrí celému národu, doslovne je to sabkibólí, jazyk každého. Bude formovaný luudom a prispôsobí sa verejným potrebám a podmienkam. Bude obsahovat' slovo nír, ako aj slová pání či džal , pretože 120 miliónov južných Indov pozná na označenie vody len slovo nír (Kalelkar, 2006, s. 43).

Po rozdelení Indie predstava o spoločnom jazyku hinduistov a moslimov padla. Hindčina a urdčina sa začali od seba čím d’alej, tým viac vzd'al'ovat', pretože urdčina stále viac používala perzsko-arabské slová a vytláčala sanskrtizmy, respektíve zo sanskrtu vytvorené slová. Podobným smerom sa vydala aj hindčina s tým rozdielom, že začala si svoju slovnú zásobu vytvárat' hlavne na základe sanskrtu a opúšt'at' slová perzsko-arabského pôvodu. Na tvorbu novej terminológie bol zriadený aj zvláštny úrad Komisia pre vedeckú a technickú terminológiu spadajúca pod ministerstvo rozvoja l’udských zdrojov (predtým ministerstvo školstva).

\subsection{PROBLEMATIKA PÍSMA}

Vel'kú čast' diskusie o národnom jazyku zabrali úvahy o písme, ktoré by malo byt' jednotné pre všetky jazyky Indie. Aj v tejto oblasti sa svojimi predstavami najviac presadzoval Mahátma Gándhí, ktorý povedal: „Som silne presvedčený, že by malo jestvovat' iba jedno písmo pre všetky indické jazyky a tým písmom by malo byt jedine dévanágarí... V súčasnosti máme bengálske písmo v Bengálsku, gurmukhí v Pandžábe, sindhské v Sindhu, gudžarátske v Gudžaráte, telugské v Ándhrapradéši, tamilské v Tamilnádu, malajálamské v Kérale, kanarské v Karnátake, nehovoriac o písme kaithí v Biháre a módí v Dakšine“ (Gandhi, 1942, s. 1).

Svojimi predstavami inšpiroval aj iných Indov, ako bol napríklad K. M. Munší: „Ak by sme mali jednotné písmo v provinciách, kde sa hovorí bengálsky, hindsky, maráthsky a gudžarátsky, obyvatelia týchto provincií by mohli polahky čítat' diela vo všetkých týchto štyroch jazykoch. V iných provinciách l'udia, ktorí by mohli čítat' v národnom jazyku, by boli schopní porozumiet' týmto dielam. Takýmto písmom by mohlo byt' jedine dévanágarí" (Munshi, 2006, s. 52). Lenže problém sa vyskytol práve pri hindčine/urdčine, pretože moslimovia sa nemienili vzdat' svojho upraveného arabského písma. K. M. Munší o tom poznamenáva: „Nie je dôvod dúfat', že sa

\footnotetext{
${ }^{5}$ Nir, pání a džal sú synonymá označujúce vodu.
} 
moslimovia vzdajú svojho urdského písma a prijmú naše (dévanágarí - pozn. P. N.). Dokonca ani hinduisti nemajú medzi sebou jednotného písma. Ako by teda bolo možné učit písmo dévanágarí a urdské všetky vzdelané osoby? Jediným praktickým riešením problému je akceptovanie písma dévanágarí tými, ktorí tak môžu bez problémov urobit'. Ostane len otázka, či dôsledkom kompromisu medzi dévanágarí a urdským písmom bude fakultatívne používanie oboch písem alebo prijatie všeobecného latinizovaného písma. "(Munshi, 2006, s. 52).

Otázkou, či by nebolo lepšie nahradit' všetky indické písma latinkou, sa zaoberal aj Gándhí vo svojom článku Roman script v. Devanagari, v ktorom však tvrdí, že: „Už prv som vyjadril svoj názor, že jediné univerzálne písmo Indie je dévanágarí... milióny hinduistov a moslimov nebudú potrebovat' znalost' latinky, pokial' sa nebudú chciet' naučit' anglicky“ (Gandhi, 1942, s. 44 - 45).

Predstavy Indov o národnom jazyku by sa dali zhrnút' do nasledujúcich bodov, ako ich sformuloval M. K. Gándhí:

1. Náš všeobecný jazyk by sa mal nazývat' hindustánčina a nie hindčina.

2. Hindustánčina sa nesmie dávat' do súvislosti s nejakou náboženskou tradíciou či komunitou.

3. Pri vyberaní slovnej zásoby sa nemá hl'adiet' na to, či sú slová domáceho či cudzieho pôvodu, ale či sú všeobecne rozšírené.

4. Všetky slová používané hinduistickými autormi píšucimi urdsky a moslimskými autormi píšucimi hindsky majú byt' považované za bežné. Nevzt’ahuje sa to však na urdčinu a hindčinu ako osobité jazyky ${ }^{6}$.

5. Pri výbere terminológie sa nemá dávat' prednost' sanskrtu, čo najväčší priestor treba ponechat' prirodzenému výberu z urdčiny, hindčiny a sanskrtu.

6. Dévanágarí a arabské písmo majú byt' považované za rozšírené a oficiálne vo všetkých inštitúciách, ktorých politika je riadená oficiálnymi podporovatel'mi hindustánčiny, a zamestnanci majú mat' možnost' naučit' sa obe písma (Gandhi, 2006, s. 69 - 70).

Ďalší vývoj tieto Gándhího myšlienky úplne znegoval. Jeho snaha zjednotit’ hinduistov a moslimov tým, že novým jazykom bude hindustánčina, ktorá do seba zahrnie hindčinu a urdčinu, bola zničená rozdelením Indie po získaní nezávislosti. Aj jeho úsilie skíbit' indoeurópsky sever s drávidským juhom stroskotalo na neutíchajúcom odpore voči hindčine, najmä zo strany Tamilov (Ram, 1968).

\section{SCHVALOVANIE HINDČINY AKO ÚRADNÉHO JAZYKA INDIE}

Pri schval'ovaní Ústavy Indickej republiky najviac času zabrala diskusia o podobe úradného jazyka - či to má byt' hindčina, alebo angličtina. Stretli sa tu dva tá-

${ }^{6}$ Najznámejším autorom, ktorý písal urdsky aj hindsky, bol hinduista Prémčand (vl. menom Dhanapat Ráj Šrívástav 1880 - 1936). 
bory: zo severu tvrdí zástancovia hindčiny a z juhu nemenej odhodlaní zástancovia zachovania angličtiny. To, akú plamennú diskusiu vyvolala táto téma, akoby predurčilo d’alší vývoj jazykovej otázky v Indii, ktorá je zdrojom problémov až dodnes.

Komisia, ktorá vytvárala návrhy ústavných noriem, prišla s témou jazyka v decembri 1946 predložením návrhu, aby ústavodarné zhromaždenie rokovalo v hindustánčine alebo angličtine a, ak to predseda dovolí, aby mohol člen zhromaždenia použit' aj svoj materinský jazyk, ale všetky záznamy sa mali viest' v hindustánčine či angličtine. K návrhu pripojili pripomienky Séth Góvind Dás, hindský „extrémista“, a Kasturiranga Santhanam, významný politik z juhoindického Madrásu. Prvý žiadal, aby jazykom zhromaždenia bola hindčina, a ak ju niekto neovláda, môže použit' svoj materinský jazyk alebo angličtinu. Druhý navrhoval, aby takýmto jazykom bola za každých okolností angličtina bez ohl'adu na to, či niektorý člen vie hindsky, alebo nie. Zhromaždenie nakoniec schválilo návrh bez týchto pripomienok (Austin, 2009, s. $53-54)$.

Vel'ký zlom v otázke jazyka nastal po rozdelení Indie, ked' sa nenávist' voči moslimom obrátila aj proti urdčine. Presadzovat' hindustánčinu ako úradný jazyk nad’alej už nebolo možné. Tvrdé jadro zástancov sanskrtizovanej hindčiny išlo až tak d’aleko, že vyžadovalo, aby hindčina, dokonca aj na regionálnej úrovni, bola prvým úradným jazykom a regionálne jazyky nasledovali až za ňou. Žiadali úplné odmietnutie angličtiny aj urdčiny ako jazykov neindických. Na druhej strane zástancovia hindustánčiny (Gándhí, Néhrú) mali nad’alej silnú autoritu. Napriek tomu začala návrhová komisia pracovat' len s termínom hindčina bez toho, aby ju tým zhromaždenie poverilo. Hindustánčina ako pojem sa stala tabu (Austin, 2009, s. 57 - 58).

Rok 1948 sa stal klúčovým pre zástancov hindčiny. Od začiatku roka sa v zhromaždení objavovali rôzne návrhy na riešenie jazykovej otázky, ktoré by sa podl’a Granvilla Austina dali zhrnút' takto: „Hindčina (bháratčina) by mala byt' národný (úradný) jazyk Indie. Dévanágarí má byt' národným písmom Indie. V provinciách, kde sa hindčina ani dévanágarí nepoužívajú, si miestne zákonodarné zbory majú samy zvolit' úradný jazyk. Provincie majú používat' angličtinu tak dlho, ako uznajú za vhodné (v niektorých návrhoch bolo jej použivanie obmedzené len na sedem- či dokonca pät'ročné obdobie). Angličtina sa môže použivat' ako druhý úradný jazyk Indie tak dlho, ako stanoví parlament. Rokovania $\mathrm{v}$ parlamente majú prebiehat' $\mathrm{v}$ hindčine a zapisovat' sa $\mathrm{v}$ písme dévanágarí. Ale parlament môže stanovit’ aj pouŽivanie angličtiny“ (Austin, 2009, s. 58 - 59).

Ďalšou snahou zástancov hindčiny bolo, aby text ústavy bol schválený v hindčine. Potom, čo myšlienka hindustánčiny stratila prestíž, boli obavy, že takýto text bude presýtený sanskrtizmami a že mu nebudú rozumiet' ani tí, ktorých materčinou je hindčina (Austin, 2009, s. 61 - 62).

V roku 1949, ktorý bol posledným v niekol'koročnom procese schval'ovania textu ústavy, sa znova vynorila otázka jazyka schváleného textu ústavy. Džaváharlál Néhrú bol proti tomu, aby bola ústava prijatá v hindskom znení a presadzoval, aby 
jej text bol schválený $\mathrm{v}$ angličtine a dodatočne preložený $\mathrm{z}$ angličtiny do hindčiny, ale na to určenými odborníkmi, nie členmi zhromaždenia. Opačné stanovisko zastával Rádžéndra Prasád, ktorý trval na hindskom znení, ale nebol ani proti schváleniu $\mathrm{v}$ angličtine s tým, že časom (po desiatich až pätnástich rokoch), ked’ si jej hindské znenie osvoja aj l'udia z juhu, bude už záväzné len hindské znenie. Argumentoval obdobným riešením, ktoré bolo použité pri írskej ústave. Néhrú sa k hindskému zneniu vyjadril $\mathrm{v}$ tom zmysle, že ak bude ústavný text schval'ovaný v hindčine, bude sa bojovat' o každé slovíčko a možnú jeho interpretáciu, zatial' čo pri anglickom texte by podl'a neho takéto problémy nehrozili. Preto sa zhromaždenie uznieslo, že schváli text ústavy v anglickom znení. Pri prekladaní ústavy do indických jazykov, a teda aj do hindčiny, sa ukázali vyššie uvedené obavy ako opodstatnené, pretože ani plynule hindsky hovoriaci Néhrú, ked' mu predložili výsledný preklad do hindčiny, nerozumel z textu takmer ani slovo (Austin, 2009, s. 66 - 67).

Diskusia na tému úradného jazyka vyvrcholila v auguste 1949. Obidva tábory stáli pevne na svojich stanoviskách, aj ked' nehindskí členovia zhromaždenia boli ochotní prijat' hindčinu ako úradný jazyk, ale s tým, že angličtina bude uznaná ako úradný jazyk popri nej, a to na obdobie dlhšie ako pätnást’ rokov, na ktoré boli ochotní pristúpit' hindskí zástupcovia. Tí však nad’alej trvali na výlučnosti hindčiny ako úradného jazyka po uplynutí tejto lehoty a v jej priebehu chceli progresívne presadzovat' používanie hindčiny, čo si nehindskí zástupcovia vykladali ako vnucovanie hindčiny proti ich vôli.

Dohodu nebolo možné dosiahnut' ani v otázke, akú formu hindčiny schválit' ako úradnú, či má byt' sanskrtizovaná podl’a predstáv tvrdého hindského jadra (teda upravená až za hranicu zrozumitel’nosti), alebo sa má vyvíjat' tak, ako si to želal Gándhí a iní zástancovia (Néhrú, Prasád) teraz už nepriechodnej hindustánčiny, teda aby sa používali slová zrozumitel'né čo najväčšej časti populácie bez ohl'adu na ich etymologický pôvod.

Ďalším bodom, na ktorom sa členovia ústavodarného zhromaždenia nevedeli zhodnút', bola podoba číslic, ktoré sa mali používat'. Hindskí zástupcovia chceli presadit' podobu číslic uplatňovanú v písme dévanágarí. Neboli ochotní z tohto návrhu zl'avit' v prospech medzinárodne používaných, tzv. arabských číslic, hoci sa ich iní členovia ústavodarného zhromaždenia snažili presvedčit’ argumentom, že ide vlastne o pozmenené formy pôvodne indických číslic. Tento chaos v rôznorodých návrhoch na riešenie jazykovej otázky a neschopnost' členov zhromaždenia dospiet' $\mathrm{k}$ nejakej dohode viedol $\mathrm{k}$ tomu, že bol zo všetkých predložených návrhov zostavený tzv. Munš́ího - Ajjangárov návrh (Austin, 2009, s. 72 - 78).

Návrh odporúčal, aby úradným jazykom Únie bola hindčina $\mathrm{v}$ písme dévanágarí a pri čísliciach sa mala používat' ich medzinárodná forma. Angličtina sa mala používat' pätnást' rokov s tým, že toto obdobie mohlo byt' predížené. Jazykom najvyššieho súdu a vrchných súdov mala byt' angličtina. Slovná zásoba hindčiny sa mala čerpat' hlavne zo sanskrtu a do ôsmeho dodatku ústavy bolo zahrnutých 13 regionál- 
nych jazykov, ale nie angličtina a sanskrt. Zákonodarné orgány zväzových štátov si mali stanovit' ako svoj úradný jazyk niektorý z regionálnych jazykov uvedených v ôsmom dodatku alebo hindčinu či angličtinu. Ďalej sa mala vytvorit' komisia, ktorá by zdokumentovala po piatich a desiatich rokoch šírenie hindčiny. Mnohé z týchto návrhov boli nakoniec schválené a prešli do textu ústavy (Austin, 2009, s. 78).

Narasinha Gópálsvámí Ajjangár uviedol tento návrh slovami, že ide o kompromis medzi značne antagonistickými názormi. Návrh stojí na dvoch princípoch a síce, že je nutné vybrat' jeden z jazykov Indie ako spoločný jazyk celej krajiny, a zároveň ponechat' aj nad’alej angličtinu, kým sa hindčina dostatočne nevyvinie, aby mohla plnit úlohu, ktorá je jej zverená. A druhým princípom bolo zavedenie formy číslic, ktorá bola označovaná ako celoindická podoba indických číslic (Austin, 2009, s. 86).

Aj o tomto návrhu nastala búrlivá debata, ale napriek zanietenosti diskutérov bolo vo vzduchu cítit' určitú únavu z nekonečného dohadovania sa o jazykovej otázke. Nakoniec v neskorých večerných hodinách 14. septembra 1949 bol Munšího Ajjangárov návrh schválený (Austin, 2009, s. 89).

Tri roky trvajúca diskusia na tému úradného jazyka ukázala, ako sa $\mathrm{k}$ nej stavali zástancovia hindčiny. Svojou neústupnost'ou a odmietaním kompromisov, teda odmietaním vypočut' a zvážit návrhy nehindských členov ústavodarného zhromaždenia, nakoniec hindčine viac uškodili, ako pomohli. Tento ich necitlivý prístup ilustruje prejav Raghunátha Vinájaka Dhulékara z 10. decembra 1946:

„L’udia, ktorí neovládajú hindustánčinu, nemajú právo zotrvávat' v Indii. L'udia, ktorí sú prítomní na tomto zhromaždení, aby vytvorili ústavu pre Indiu a nevedia hindsky, nie sú hodní byt' členmi tohto zhromaždenia. Bolo by lepšie, keby odišli ““ (Guha, 2007, s. 117).

Preto nezarážajú ani slová, ktoré vyriekol Tiruvallúr Tannai Krišnamáčárí z Madrásu, ked' bolo rozhodnuté, že hindčina bude jediný úradný jazyk Indie:

„Ak budeme nútení učit' sa hindčinu... nebudem sa ju schopný naučit' kvôli môjmu veku a možno ani nebudem chciet' kvôli nátlaku, ktorý na mňa vyvíjate... Tento druh neznášanlivosti nás núti obávat' sa, že silné centrum, ktoré potrebujeme, ako aj silné centrum, ktoré je nevyhnutné, bude tiež znamenat' zotročenie l'udí, ktorí nehovoria jazykom centra. Vyslovujem varovanie na podnet l'udí z juhu s úmyslom oznámit', že existujú skupinky v južnej Indii, ktoré si prajú odtrhnutie... a moji ctení priatelia z Uttarpradéša, nijako nepomáhajte vyostrit' ideu „hindského imperializmu“ do krajného maxima“" (Guha, 2007, s. 120).

Problematika celoindického úradného jazyka sa schválením ústavy neskončila, skôr naopak. Jazyková otázka (či už hindčiny, angličtiny alebo iných regionálnych indických jazykov) sa stala neodlučitel’nou súčast'ou politického života nezávislej Indie, a to najmä počas tzv. prechodného obdobia v trvaní pätnást' rokov, ktoré ústava stanovila na to, aby si všetky úrady a vládne inštitúcie namiesto angličtiny osvojili a používali hindčinu. Mnohé politické strany z nehindsky hovo- 
riacich štátov využili otázku jazyka na boj proti politike centra a na obranu svojich regionálnych záujmov. ${ }^{7}$

Ústavným uzákonením hindčiny ako celoindického úradného jazyka nastalo pre ňu kvalitatívne a kvantitatívne nové obdobie. Boli založené rôzne inštitúcie a úrady na šírenie a propagáciu hindčiny. Rapídne vzrástol počet vedeckých publikácií písaných hindsky, prenikla na vysokoškolskú pôdu, kde začala konkurovat' dovtedy výlučnej angličtine. Na nižších stupňoch škôl sa začala učit ako povinný jazyk spolu s angličtinou a regionálnym jazykom (na tieto účely bola vytvorená tzv. trojjazyčná formula vyučovania jazykov na školách). Komplexnost' témy postavenia hindčiny v samostatnej Indii presahuje predmet tohto článku. Podrobnejšie sa tomu budeme venovat' $\mathrm{v}$ inom príspevku.

\section{ZÁVER}

V článku sme chceli ukázat’, že kým sa hindčina presadila ako úradný jazyk Indie v konkurencii s angličtinou, ale aj inými indickými jazykmi, prešla dlhým vývojom. Z množstva hindských dialektov sa ako jazyk štátnej správy, a omnoho neskôr aj literatúry, ujal dialekt kharíbólí, ktorým sa hovorí v okolí dnešného Dillí. Okrem hindčiny je tento dialekt aj základom urdčiny, úradného jazyka Pakistanu. Oba jazyky tak majú spoločný gramatický aj lexikálny základ, odlišnosti sú dané slovnou zásobou v odbornej terminológii, ale najmä jazykovou politikou oboch krajín.

Postoj k hindčine ako úradnému jazyku celej Indie prešiel značne turbulentným vývojom. Na začiatku národnooslobodzovacieho hnutia a hlavne $\mathrm{v}$ jeho vrcholnom období v 30. a 40. rokoch 20. storočia bola hindčina, respektíve jej hovorová forma hindustánčina, ktorá zahrnovala aj hovorovú urdčinu, prijímaná širokým spektrom indických politikov ako národný jazyk samostatnej Indie. Mnohí politici, ale aj iní významní činitelia spoločenského života, sa vyjadrovali k otázke národného jazyka. $\mathrm{Z}$ ich myšlienok sme tu mohli vzhl'adom na obmedzený rozsah textu upozornit' len na tie najpodstatnejšie.

Drastický rozpad Indie na prahu jej nezávislosti sa prejavil aj v otázke národného jazyka. Muslimsko-hinduistická nevraživost' sa premietla aj do zápasu o podobu národného jazyka. Odmietnutie urdčiny zabránilo schválit' hindustánčinu ako národný jazyk Indie, ktorá v sebe spájala tak moslimskú, ako aj hinduistickú zložku indickej kultúrnej tradície. Prevahu získali zástancovia sanskrtizovanej hindčiny (najmä slovnou zásobou a čiastočne aj gramaticky postavenej na sanskrte). Necitlivý prístup pri presadzovaní takejto formy národného jazyka spôsobil, že značná čast' nehindsky hovoriacich politikov začala vidiet' $\mathrm{v}$ hindčine nástroj nadvlády politikov $\mathrm{z}$ hindsky

${ }^{7}$ Podrobnejšie sa tejto problematike venuje Jyotindra Das Gupta v práci Language Conflict and National Development (1970). 
hovoriacich oblastí nad ostatnými Indmi a začali sa prikláňat' k angličtine. Prejavilo sa to pri schválení Ústavy Indie, ked' popri hindčine nad’alej zostáva celoindickým úradným jazykom angličtina a o hindčine sa už nehovorí ako o národnom jazyku, ale len ako o štátnom (úradnom) jazyku.

S povojnovým rozvojom sociolingvistiky sa začína odborná verejnost' zaujímat' o hindčinu aj z pohl'adu, ako sa uplatňuje v nezávislej Indii v konkurencii s angličtinou a ako je prijímaná v nehindsky hovoriacich oblastiach (štátoch) Indie. Literatúra $\mathrm{k}$ tejto problematike, najmä západnej proveniencie, nadobudla najväčší rozsah v 60. a začiatkom 70. rokov minulého storočia. Odvtedy cítit' určitý útlm a dôraz sa kladie skôr na ekonomické a politické problémy súčasnej Indie. Problematika postavenia hindčiny, ale aj iných regionálnych jazykov Indie, je aj v súčasnosti nad’alej vel'mi pestrá a hodná podrobnejšieho d’alšieho štúdia, najmä pre iné mnohojazyčné krajiny či zoskupenia, medzi ktoré patrí hlavne súčasná Európska únia.

\section{Literatúra}

AUSTIN, Granville: Language and the Constitution. The Half-Hearted Compromise. In: Language and Politics in India. Ed. A. Sarangi. New Delhi: Oxford University Press 2009, s. 41 - 92.

BARANNIKOV, Alexej Petrovič: Problemy chindi kak nacional'nogo jazyka. Leningrad: Nauka 1972.

ČATERDŽÍ, Sunitikumár: Bhártíj árjabhášá aur hindí. Dillí: Rádžkamal Prakášan 1957.

GÁNDHÍ, Móhandás Karamčand: Hindísvarádž. Indická samospráva. Brno: Doplněk 2003.

GANDHI, Mahatma: National Language for India. In: Language in Contemporary India. Ed. S. K. Sharma. Delhi: Vista International Publishing House 2006, s. 67 - 71.

GANDHI, Mahatma: Our Language Problem. Karachi: Anand T. Hingorani 1942.

GOPAL, Ram: Linguistic Affairs of India. Bombay: Asia Publishing House 1966.

GUHA, Ramachandra: India after Gandhi: The History of Largest Democracy. London: Macmillan 2007.

GUPTA, Jyotindra Das: Language Conflict and National Development. Group Politics and National Language Policy in India. Berkeley: University of California Press, 1970. 293 s.

KALELKAR, Kaka: National Language for India. In: Language in Contemporary India. Ed. S. K. Sharma. Delhi: Vista International Publishing House 2006, s. 39 - 44.

MUNSHI, Kanaiyalal, Maneklal: National Language for India. In: Language in Contemporary India. Ed. S. K. Sharma. Delhi: Vista International Publishing House 2006, s. 49 - 53.

NAGY, Peter: Hindčina a jazyková politika Indie. Diplomová práca. Filozofická fakulta KU, Praha 2010.

RAM, Mohan: Hindi against India. New Delhi: Rachna Prakashan 1968.

TAYLOR, Joseph: A Common Script for India. In: Language in Contemporary India. Ed. S. K. Sharma. Delhi: Vista International Publishing House 2006, s. 45 - 48. 